\title{
Pengaruh Dyadic Coping terhadap Kepuasan Pernikahan Pada Pasangan Menikah di Tangerang
}

\author{
Soesanto Dermawan ${ }^{1}$, \\ Yonathan Aditya Goei, \\ Kartika Chandra Kirana \\ Fakultas Psikologi \\ Universitas Pelita Harapan \\ Jl. MH. Thamrin Boulevard, Lippo Karawaci, \\ Tangerang 15811, Indonesia \\ ${ }^{1}$ e-mail: soesanto.dermawan@live.com
}

\begin{abstract}
Marital satisfaction is one of the important topics in marital research, because marital satisfaction has major influence on marital stability. One factor that affects marital satisfaction is dyadic coping. This study tested the effect of positive and negative dyadic coping on marital satisfaction. Data was gained from 115 couples. Actor-Partner Interdependence Model (APIM) was used to guide the analysis and calculation was done with multiple level regression. The result indicated significance actor effects from both positive dyadic coping and negative dyadic coping on marital satisfaction. However, none of partner effect was found significant.
\end{abstract}

Keywords: positive dyadic coping; negative dyadic coping; marital satisfaction

\begin{abstract}
Abstrak - Kepuasan pernikahan merupakan salah satu faktor penting dalam penelitian tentang pernikahan, karena kepuasan pernikahan banyak mempengaruhi kestabilan pernikahan. Salah satu faktor mempengaruhi kepuasan pernikahan adalah dyadic coping. Penelitian ini menguji pengaruh positive dan negative dyadic coping pada kepuasan pernikahan. Data didapatkan dari 115 pasangan. Analisa data dipandu oleh Actor-Partner Interdependence Model (APIM), sedangkan perhitungan data menggunakan multi level regression. Hasil perhitungan menunjukkan adanya pengaruh yang signifikan dari positive dyadic coping dan negative dyadic coping terhadap marital satisfaction pada actor effect, namun tidak signifikan pada partner effect.
\end{abstract}

Kata kunci: positive dyadic coping; negative dyadic coping; kepuasan pernikahan 


\section{PENDAHULUAN}

Pernikahan merupakan hal yang penting dalam masyarakat sekaligus bentuk pemenuhan kebutuhan sosial, emosi, maupun fisik, khususnya mereka yang memasuki jenjang dewasa. Keputusan untuk menikah juga berarti titik akhir pencarian pasangan dalam membangun suatu hubungan intim yang serius dan berkepanjangan (Papalia, Olds, \& Feldman, 2007). Kepuasan pernikahan merupakan topik yang sering menjadi topik pembicaraan hangat di antara semua faktor dalam pernikahan (Reis \& Sprecher, 2009).

Kepuasan pernikahan sangatlah penting untuk diperhatikan karena dapat mempengaruhi aspek-aspek kehidupan individu seperti kesehatan mental, daya tahan terhadap depresi (Tesser \& Beach, dalam Randall \& Bodenmann, 2009), kesehatan fisik (Cotton, dalam Santrock, 2006), serta kinerja seseorang (Renick, Blumberg, \& Markman, dalam Randall \& Bodenmann, 2009). Secara umum, kepuasan pernikahan merupakan penunjang kepuasan hidup seseorang secara general (life satisfaction) (Ruvolo, 1998), dan tentunya setiap individu ingin merasa bahagia (Compton, 2005). Faktanya, tidak semua pasangan yang telah menikah memiliki pernikahan yang bahagia sehingga berlanjut pada perceraian. Peningkatan kasus perceraian di Indonesia terjadi dari 8,80\% (2008) menuju 12.92 (2010) (Badan Pusat Statistik, 2011).

Salah satu penyebab rendahnya kepuasan pernikahan ialah "dyadic stress" yang tidak diselesaikan dengan baik (Bodenmann, 2005). Dyadic stress dapat bersumber dari internal maupun eksternal pasangan, seperti pola interaksi antar pasangan yang buruk, kepribadian pasangan yang mengganggu, stress pekerjaan, ataupun kondisi anak. Oleh karena itu, diperlukannya suatu proses yang dapat menanggulangi bahaya dari dyadic stress yang dikenal sebagai "dyadic coping”. Dyadic coping adalah coping yang dilakukan oleh kedua pasangan untuk menghadapi dyadic stress berdasarkan sumber daya mereka. Ketika individu mengkomunikasikan stress yang dialaminya (secara verbal atau non verbal), pasangan dapat merespon dengan dua cara, yaitu supportive atau unsupportive (Bodenmann, 1997). Respon inilah yang menentukan kesuksesan individu dan pasangannya dalam mengatasi stress tersebut (Cutrona \& Gardner, 2006). Bodenmann (2005) membagi dyadic coping menjadi dua yaitu dyadic coping positif dan dyadic coping negatif. Dua jenis dyadic coping ini berbeda secara konseptual dan bukan merupakan komplimentari satu sama lain. Setiap pasangan mempunyai dua jenis coping ini dan bisa saja ada pasangan yang mempunyai dua jenis coping ini dalam tingkat yang sama tingginya.

Selain berfungsi untuk menghadapi dyadic stress, dyadic coping juga berperan dalam 
meningkatkan kepuasan pernikahan pasangan (Bodenmann, 2005). Hal yang serupa dinyatakan oleh Kupst dan Schulman (dalam Hoekstra-Weebers, Jaspers, Kamps, \& Klip, 1998), yaitu bahwa pola coping yang digunakan oleh pasangan akan menentukan kualitas pernikahan mereka. Peningkatan tersebut terjadi karena adanya keintiman untuk saling menjaga kesejahteraan satu sama lain (Bodenmann, 2005; Clark, Lemay, Graham, Pataki, \& Finkel, 2010). Artinya, kesejahteraan individu dapat dipengaruhi oleh kesejahteraan pasangannya (mutual influence) (Bodenmann, 2005).

Penelitian ini bertujuan untuk mengukur seberapa besar kontribusi dari dyadic coping terhadap kepuasan pernikahan pasangan menikah di Tangerang. Pemilihan Tangerang sebagai wilayah dari fokus penelitian adalah karena Tangerang merupakan kota industri yang sedang berkembang (Dinas Informasi dan Komunikasi Pemerintah Kota Tangerang, 2010). Menurut Lederbogen, dkk. (2011), masyarakat kota berkembang lebih beresiko menghadapi stress seharihari. Adapun salah satu stress tersebut adalah tuntutan finansial terkait dengan kebutuhan hidup (Bowen, Pittman, Pleck, Haas, \& Voydanoff, dalam Olson \& DeFrain, 2003). Selain itu, peran menjadi orangtua juga merupakan stress bagi pasangan yang telah memiliki anak (Hess, 2008; Bradbury, dkk., 2000; Olson \& DeFrain, 2003; Sanders, 2010). Pada sisi lain, stress akibat pekerjaan (job related stress) hingga kehilangan pekerjaan (job loss) juga dapat mempengaruhi marital satisfaction (Bradbury,dkk., 2000; Yoneda \& Davila, 2006; Mauno \& Kinnunen, 1999; Story \& Repetti, 2006). Hasil dari penelitian ini diharapkan mampu memberikan manfaat praktis bagi masyarakat maupun lembaga-lembaga yang bergerak di bidang pemberdayaan pernikahan masyarakat Tangerang.

\section{Masalah Penelitian}

Bagaimana pengaruh positive dyadic coping dan negative dyadic coping terhadap kepuasan pernikahan diri sendiri maupun pasangannya?

\section{Hipotesa}

1. Positive dyadic coping mempunyai pengaruh positif terhadap kepuasan pernikahan diri sendiri maupun pasangan.

2. Negative dyadic coping mempunyai pengaruh negatif terhadap kepuasan pernikahan diri sendiri maupun pasangan. 


\section{METODE}

\section{Partisipan}

Penelitian ini melibatkan 115 sampel pasangan yang telah menikah dan menetap di Tangerang. Sampel berasal dari berbagai karakteristik suku dan agama menggunakan convenience sampling.

\section{Desain}

Penelitian ini menggunakan metode kuantitatif dengan desain non-eksperimental, yaitu peneliti tidak mengontrol independent variable atau variable bebas terkait dengan topik penelitian (Kerlinger \& Lee, 2000). Alasan penggunaan metode kuantitatif adalah karena metode ini dapat mengukur variabel spesifik sesuai tujuan penelitian, serta menggunakan pengolahan statistik sebagai dasar interpretasi untuk menjawab perumusan masalah. Selain itu, pendekatan yang dilakukan bersifat kausal karena peneliti ingin mengukur pengaruh dyadic coping terhadap kepuasan pernikahan.

\section{Prosedur}

Peneliti menyebarkan kuesioner kepada sampel sesuai kriteria-kriteria yang telah ditentukan melalui koordinator gereja-gereja, orangtua teman-teman, serta staff-staff Universitas Pelita Harapan. Lokasi penyebaran data meliputi gereja serta perumahan di sekitar kawasan Karawaci dan Gading Serpong. Dari 300 pasang kuesioner yang terkumpul, 115 kuesioner diambil karena diisi secara lengkap.

Kuesioner yang digunakan adalah Dyadic Coping Inventory (Bodenmann, 2008) dan Relationship Assesment Scale (Hendrick, 1988). Hasil uji reliabilitas menunjukkan $\alpha=.916$ untuk positive dyadic coping pria, $\alpha=.910$ untuk positive dyadic coping wanita, $\alpha=.785$ untuk negative dyadic coping pria, $\alpha=.788$ untuk negative dyadic coping wanita, $\alpha=.790$ untuk kepuasan pernikahan pria, dan $\alpha=.838$ untuk kepuasan pernikahan wanita. Dengan demikian dapat dikatakan bahwa reliabilitas DCI dan RAS tergolong cukup baik hingga sangat baik (berdasarkan kriteria nilai reliabilitas dari Sugiyono, 2012). Hasil uji normalitas menunjukkan $p=.200$ untuk positive dyadic coping pria, $p=.200$ untuk positive dyadic coping wanita, $p=.052$ untuk negative dyadic coping pria, $p=.200$ untuk negative dyadic coping wanita, $p=.067$ untuk kepuasan pernikahan pria, dan $p=.058$ untuk kepuasan pernikahan wanita. Dengan demikain, dapat disimpulkan bahwa keseluruhan data berdistribusi normal. 


\section{Teknik Analisis}

Pengolahan data pada penelitian ini menggunakan program SPSS 20.0. Pertama-tama, peneliti melakukan uji validitas menggunakan metode analisis statistik corrected item total correlation, dan uji reliabilitas menggunakan metode analisis cronbach alpha. Selanjutnya peneliti melakukan uji normalitas dari distribusi sampel menggunakan uji Kolmogorov-Smirnov. Kemudian untuk menguji hipotesa, peneliti menggunakan Actor-Partner Interdependence Models (APIM). Melalui APIM, peneliti mampu mengukur pengaruh dari independent variable responden terhadap dependent variable-nya sendiri (actor effect) serta terhadap dependent variable pasangannya (partner effect) (Ackerman, Donnelan, \& Kashy, 2010).

Sebelum perhitungan dapat dilakukan, perlu dilakukan Omnibus Test of Distinguishability untuk memeriksa apakah benar data dari suami dan istri dalam penelitian ini berbeda secara empiris (Kenny, Kashy \& Cook, 2006). Hasil analisa menunjukkan adanya perbedaan secara empiris dari data suami dan istri dalam penelitian ini oleh karena itu dipakai APIM untuk pasangan yang dapat dibedahkan (distinguishable dyad).

Untuk menganalisa data dengan pendekatan APIM, peneliti menggunakan teknik analisis statistik Multilevel Modeling (MLM) (disebut juga sebagai Hierarchical Linear Modeling), karena data dalam penelitian ini terdiri dari dua tingkat: tingkat pertama adalah dyad dan tingkat kedua adalah suami dan istri.

\section{ANALISIS DAN HASIL}

Peneliti melakukan analisis data demografis untuk pada tahap awal, seperti jenis kelamin, usia responden, usia pernikahan, jumlah anak, kemampuan finansial, beban pekerjaan, pendidikan terakhir, agama, serta suku ras.

Selanjutnya, peneliti melakukan uji pengaruh yang menunjukan adanya pengaruh yang signifikan $(p<.05)$ pada actor effect (Positive dyadic coping pria terhadap kepuasan pernikahan pria, negative dyadic coping pria terhadap kepuasan pernikahan pria, positive dyadic coping wanita terhadap kepuasan pernikahan wanita, negative dyadic coping wanita terhadap kepuasan pernikahan wanita, namun tidak signifikan pada partner effect. 


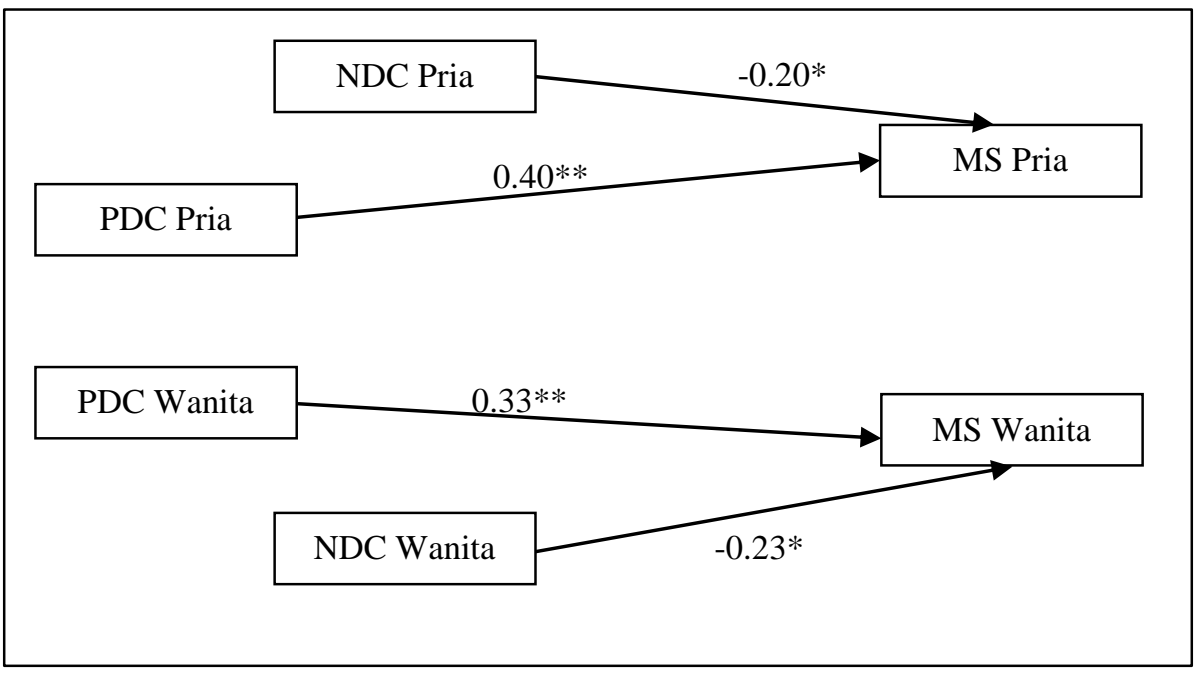

Gambar 1. Gambar Hasil Analisis Pengaruh PDC dan NDC terhadap MS.

Keterangan:

${ }^{*} p<.05, * * p<.01$;

$\mathrm{PDC}=$ Positive Dyadic Coping, $\mathrm{NDC}=$ Negative Dyadic Coping, $\mathrm{MS}=$ Marital Satisfaction.

Pada akhir analisis, hasil analisis data tambahan menunjukan adanya hubungan yang signifikan antara kemampuan finansial dengan kepuasan pernikahan $(r=.157, p=.018, p<.05)$, tingkat pendidikan dengan kepuasan pernikahan $(r=.164, p=.013, p<.05)$, kepuasan pernikahan pria dengan kepuasan pernikahan wanita $(r=.635, p=.000, p<.05)$, positive dyadic coping pria dengan positive dyadic coping wanita $(r=.595, p=.000, p<.05)$, dan negative dyadic coping pria dengan negative dyadic coping wanita $(r=.502, p=.000, p<.05)$.

\section{DISKUSI}

Tujuan dari penelitian ini adalah untuk mengukur pengaruh positive dyadic coping dan negative dyadic coping terhadap kepuasan pernikahan berdasarkan actor-partner interdependence model (APIM). Adapun APIM melalui analisis MLM memberikan kesempatan untuk mengukur actor effect dan partner effect secara bersamaan. Hasil analisis menunjukkan bahwa penggunaan positive dyadic coping berpengaruh dalam meningkatkan kepuasan pernikahan. Pada sisi lain, penggunaan negative dyadic coping dalam pernikahan dapat menurunkan tingkat kepuasan pernikahan.

Melalui positive dyadic coping, pasangan akan saling terbuka secara emosional, saling berbagi kesulitan, dan saling membantu satu sama lain dalam bentuk yang lebih positif, karena 
melalui hubungan "saling" itulah individu merasa dihargai dan dipedulikan oleh pasangannya (Olson \& DeFrain, 2003; Badr, Carmack, Kashy, Cristofanilli, \& Revenson,2010). Kondisi tersebut akhirnya menumbuhkan kohesivitas, kepercayaan, dan komitmen dalam pernikahan sehingga meningkatkan kepuasan pernikahan mereka (Bodenmann, 2005). Jadi hasil penelitian ini sejalan dengan salah satu fungsi dyadic coping, yaitu berperan dalam meningkatkan kualitas hubungan pasangan dan pernikahan (Bodenmann, 2005; Hoekstra-Weebers, Jaspers, Kamps, \& Klip, 1998).

Sementara itu, penggunaan negative dyadic coping dapat membawa pengaruh yang negatif bagi pernikahan. Berbagai sikap seperti menyalahkan pasangan ketika memberi bantuan, tidak menanggapi stress-nya dengan serius, atau menjauh ketika pasangannya menceritakan permasalahan yang sedang dihadapi dapat menyakiti perasaan pasangan, baik secara langsung ataupun tidak langsung (Stone \& Shackelford, 2006; Bodenmann, Meuwly, Bradbury, Gmelch, Ledermann, 2010). Sikap-sikap tersebut kemudian menumbuhkan atribusi atau emosi negatif terhadap pernikahan sehingga dapat menurunkan kepuasan pernikahan (Cutrona \& Gardner 2006; Bodenmann, 2005).

Berdasarkan APIM, peneliti juga mengukur pengaruh positive dyadic coping dan negative dyadic coping terhadap kepuasan pernikahan melalui actor effect dan partner effect. Terlihat adanya pengaruh yang signifikan $(p<.05)$ terdapat pada actor effect, namun tidak pada partner effect. Hal ini menunjukkan bahwa kepuasan pernikahan individu dapat diprediksi melalui persepsinya terhadap situasi pernikahannya (actor effect), namun tidak melalui persepsi pasangannya (partner effect).

Temuan di atas berbeda dengan beberapa hasil penelitian sebelumnya yang menemukan bahwa partner effect memiliki pengaruh yang signifikan (Bodenmann \& Cina, 2006; Papp \& Witt, 2010), khususnya partner effect pria terhadap wanita. Pada penelitian ini, seluruh pengaruh partner effect, baik dari positive dyadic coping maupun negative dyadic coping, terhadap kepuasan pernikahan tidaklah signifikan. Dapat dikatakan bahwa baik pria maupun wanita tidak berbeda dalam mengevaluasi kualitas pernikahannya berdasarkan pengaruh dyadic coping pasangannya.

Hal tersebut dapat dikarenakan oleh perbedaan kultur yang berpengaruh terhadap ekspetasi atau pengharapan individu akan pernikahan sehingga berpengaruh pula terhadap bagaimana individu mengevaluasi pernikahannya (Lucas, Parkhill,Wendorf, Imamoglu, Weisfeld, Weisfeld, Shen., 2008; Levine, Sato, Hashimoto, Verma, 1995). Setiap individu yang memutuskan untuk menikah tentunya memiliki pengharapan bahwa pasangannya akan memenuhi kebutuhannya, baik secara fisik maupun emosi (Olson \& DeFrain, 2003). Harapan tersebut kemudian dievaluasi berdasarkan sikap dari pasangannya, kemudian kesesuaian antara harapan dengan realita tersebut 
dapat mempengaruhi kepuasan pernikahan individu tersebut (Stone \& Shackelford, 2006; Waller \& McLanahan, 2005). Semakin tinggi harapan yang dipenuhi oleh pasangannya, maka semakin tinggi pula kepuasan pernikahan dari individu tersebut. Sebaliknya, semakin rendah harapan yang dipenuhi oleh pasangannya, maka semakin rendah pula kepuasan pernikahan individu tersebut. Oleh karena itu, tidaklah mengherankan jika beberapa penelitian sebelumnya (yang mengacu pada konteks barat) menemukan bahwa evaluasi kepuasan pernikahan individu dapat dipengaruhi oleh sikap dyadic coping pasangannya, khususnya bagi wanita. Misalnya sebagaimana ditemukan oleh Bodenmann \& Cina, (2006), yaitu bahwa dyadic coping pria merupakan prediktor bagi wanita dalam mengevaluasi kepuasan pernikahan.

Pada kultur barat, pemenuhan kebutuhan personal dianggap lebih penting sehingga hal tersebut dapat menjadi faktor yang terutama dalam mengevaluasi pernikahan. Sementara pada kultur Asia, tampaknya harapan dalam pernikahan individu tidaklah semata-mata didasarkan pada sikap dyadic coping pasangannya, melainkan dapat muncul dalam bentuk yang berbeda. Misalnya adalah keberadaan anak laki-laki (terutama China) (Levine,dkk,1995), kehadiran anak untuk melanjutkan garis keturunan (Lucas,dkk, 2008), atau peningkatan finansial (Desai \& Andrist, 2010).

Hasil analisis korelasi Pearson menunjukkan adanya hubungan yang signifikan antara kemampuan finansial dengan kepuasan pernikahan. Kemampuan finansial merupakan salah satu bentuk perlindungan bagi keluarga dan kemampuan finansial yang mencukupi dapat menimbulkan perasaan aman terhadap pemenuhan kebutuhan rumah tangga (Stone \& Shackelford, 2006). Hasil ini sejalan dengan yang diungkapkan oleh Olson dan DeFrain (2003), yaitu bahwa kemampuan finansial yang tidak mencukupi dapat menjadi stressor di dalam pernikahan dan dapat menurunkan kepuasan pernikahan pasangan.

Selain itu, tingkat pendidikan juga memiliki hubungan yang signifikan dengan dengan kepuasan pernikahan. Allendorf dan Ghimire (2012) menjelaskan bahwa tingkat pendidikan berhubungan dengan kepuasan pernikahan melalui pola komunikasi. Semakin tinggi tingkat pendidikan, maka semakin baik pula kemampuan individu untuk mengkomunikasi pendapat dan perasaan dengan cara yang lebih baik sehingga meningkatkan kualitas hubungan pernikahannya. Dengan demikian, hasil penelitian ini sesuai dengan yang dinyatakan oleh Bodenmaan (2005), yaitu bahwa pola komunikasi individu dapat mempengaruhi persepsi pasangannya terhadap dirinya dan pernikahan mereka. Bodenmann, Meuwly, dan Kayser (2011) juga berpendapat bahwa tingkat pendidikan berhubungan dengan kepuasan pernikahan melalui status pekerjaan. Semakin tinggi tingkat pendidikan, maka semakin tinggi pula kesempatan individu tersebut mendapat status pekerjaan dengan pendapatan yang tinggi, dan dengan demikian semakin tinggi pula kemampuan 
finansial individu. Pernyataan ini terbukti melalui penelitian ini dengan hasil analisis korelasi Pearson, yang menunjukkan adanya hubungan antara tingkat pendidikan dengan kemampuan finansial $(r=.163, p=.013, p<.05)$.

Melalui analisis korelasi Pearson, terlihat adanya hubungan yang signifikan antara kepuasan pernikahan pria dengan kepuasan pernikahan wanita. Hal ini berarti semakin tinggi kepuasan pernikahan suami, maka semakin tinggi kepuasan pernikahan istri, begitu pun sebaliknya. Ketika membangun sebuah hubungan yang intim, masing-masing individu berupaya untuk saling menjaga kesejahteraan satu sama lain, sehingga kesejahteraan pasangan merupakan hal yang sangat penting (Bodenmann, 2005). Upaya tersebut dapat muncul dalam bentuk memberikan perhatian, memenuhi kebutuhan pasangan, sampai membantu pasangan menghadapi persoalan yang dihadapinya, yang kemudian meningkatkan kepuasan pernikahan pasangannya. Apabila individu merasa bahagia dalam pernikahannya, semakin tinggi kecenderungan untuk kembali menjaga kesejahteraan pasangannya. Pada akhirnya hubungan timbal balik tersebut saling meningkatkan kebahagian pernikahan masing-masing individu baik pria maupun wanita (Bodenmann, 1997; Kardatzke, 2009).

Hubungan yang signifikan positif juga terlihat diantara positive dyadic coping pria dengan positive dyadic coping wanita, dan negative dyadic coping pria dengan negative dyadic coping wanita. Menurut Bodenmann (2005), dyadic coping merupakan upaya untuk mengatasi dyadic stress secara bersama-sama, sekaligus berkontribusi terhadap kepuasan pernikahan. Semakin sering positive dyadic coping dilakukan dalam pernikahan, semakin tinggi pula kepuasan pernikahan pasangannya. Ketika seorang pasangan merasa bahagia, maka motivasi untuk menjaga kebahagian pernikahan mereka melalui positive dyadic coping pun semakin tinggi. Pada sisi lain, semakin sering individu melakukan negative dyadic coping, maka semakin rendah kebahagian pernikahan pasangannya. Rendahnya kepuasan pernikahan yang dirasakan oleh pasangan dapat menahan dia untuk merespon kebutuhan pasangan dengan empati ataupun mendukung pasangannya. Pada akhirnya, justru bentuk negative dyadic coping yang muncul (Bodenmann, 1995).

\section{SIMPULAN DAN SARAN}

\section{Simpulan}

Positive dyadic coping berpengaruh dalam meningkatkan kepuasan pernikahan. Pada sisi lain, negative dyadic coping berpengaruh dalam menurunkan tingkat kepuasan pernikahan. Lebih 
lanjut, pengaruh yang signifikan dari positive dyadic coping dan negative dyadic coping terhadap kepuasan pernikahan terdapat pada actor effect, sedangkan pada partner effect, tidak terdapat pengaruh yang signifikan dari positive dyadic coping dan negative dyadic coping terhadap kepuasan pernikahan yang dapat disebabkan oleh faktor budaya. Sumbangsih pengaruh positive dyadic coping dan negative dyadic coping terhadap kepuasan pernikahan diketahui berkisar pada $20 \%$ $40 \%$ pada masing-masing individu, di mana sisanya dipengaruhi oleh faktor-faktor lain diluar variabel.

Penelitian ini memiliki beberapa keterbatasan yaitu: pertama, pengambilan sampel yang tidak didasarkan pada jenis dyadic stress tertentu melainkan secara umum, sementara pola dyadic coping dalam pernikahan dapat dibentuk oleh situasi dyadic stress serta cara pasangan menafsirkan dyadic stress tersebut (Bodenmann, 2005). Kedua, penggunanan kuesioner dapat menjadi keterbatasan penelitian karena memberikan kebebasan kepada responden untuk memilih jawaban yang dianggap lebih disesuai di mata masyarakat pada umumnya (social desirability). Walau demikian, metodologi dalam penelitian ini berkontribusi terhadap temuan yang lebih akurat. Sampel pada penelitian melibatkan kedua pasangan suami istri. Hal ini memungkinkan analisis berdasarkan persepsi dari suami dan istri terhadap situasi pernikahan mereka. Di samping itu, penelitian ini berlandaskan dasar pemikiran pada dyadic statistic yang memungkinkan analisis dengan APIM yang mampu memberikan gambaran pengaruh dyadic coping terhadap kepuasan pernikahan dalam hubungan interpersonal suami istri melalui actor effect dan partner effect.

\section{Saran Teoretis}

Untuk penelitian selanjutnya, diharapkan dapat fokus pada sampel penelitian dalam populasi tertentu, seperti pasangan dengan anak berkebutuhan khusus atau pasangan yang keduanya bekerja, sehingga mampu memberikan gambaran dyadic coping berdasarkan situasi dyadic stress tertentu. Hasil penelitian ini juga menunjukkan bahwa pengaruh actor effect dari positive dyadic coping dan negative dyadic coping terhadap kepuasan pernikahan berkisar pada $20 \%$ - 40\%, di mana sisanya dipengaruhi oleh faktor lain. Oleh karena itu, penelitian selanjutnya diharapkan dapat mengukur pengaruh dari faktor lainnya seperti pola penyesuaian diri pada pasangan beda ras, kesempatan untuk memilih pasangan, ataupun pola attachment terhadap kepuasan pernikahan pasangan di Tangerang.

Penelitian ini tidak menemukan adanya pengaruh signifikan pada partner effect yang 
kemungkinan diakibatkan oleh perbedaan kultur budaya masyarakat terhadap harapan-harapan dalam pernikahan. Oleh karena itu, penelitian selanjutnya diharapkan dapat meneliti lebih lanjut mengenai harapan dalam pernikahan yang dibentuk oleh budaya setempat.

\section{Saran Praktis}

Bagi masyarakat, khususnya individu yang telah menikah di Tangerang, diharapkan untuk dapat meningkatkan sikap-sikap positive dyadic coping seperti dengan memperlihatkan rasa simpati, mengekspresikan bahwa diri berada di pihak pasangan, saling menyemangati, membantu pasangan untuk melihat situasti pasangan dengan cara lain, menganalisa keadaan dan mencari solusi bersama-sama, memberikan masukan-masukan praktis, menggantikan melakukan tanggung jawab yang biasanya dilakukan pasangan, atau menghabiskan waktu luang bersama-sama dengan melakukan kegiatan yang menyenangkan dan tidak menyalahkan pasangan. Selain itu, penting untuk juga menghindari sikap-sikap negative dyadic coping seperti misalnya, tidak peduli ketika pasangannya menceritakan masalah, merasa bantuan yang diberikan tidak akan berarti apa-apa, menyepelekan permasalahan yang dialami oleh pasangan, memberikan dukungan dengan perasaan terpaksa, menutup diri terhadap masalah pasangan, atau membantu pasangannya dengan disertai sindiran atau kritikan tajam. Dengan meningkatkan sikap-sikap positive dyadic coping yang konstruktif bagi pernikahan, dan menjauhi sikap-sikap negative dyadic coping yang kurang baik, hal tersebut akan berpengaruh terhadap peningkatan kepuasan dalam pernikahan.

Bagi lembaga-lembaga masyarakat yang bergerak di bidang pernikahan, diharapkan untuk terus melaksanakan penyuluhan, seminar, ataupun kelas-kelas pelatihan dalam meningkatkan mutu kualitas pernikahan masyarakat setempat baiknya pra maupun pasca menikah berdasarkan hasil penelitian yang telah diterbitkan mengenai dyadic stress, dyadic coping, serta kepuasan pernikahan, sebagai contoh materi-materi dari couples coping. 


\section{REFERENSI}

Ackerman, R. A., Donnellan, M. B., \& Kashy, D. A. (2010). Romantic relationships in emerging adulthood. F. D. Fincham, \& M. Cui (Ed.). Cambridge: Cambridge University Press.

Allendorf, K. \& Ghimire, D. (2012). Determinants of marital quality in an arranged marriage society. Population Studies Center, 12, 758-780.

Badan Pusat Statistik. (2011). Nikah, talaq dan cerai, serta rujuk, 2008-2010. Jakarta: Author.

Badr, H., Carmack, C. L. Kashy, D. A., Cristofanilli, M. \& Revenson, T. A. (2010). Dyadic coping in metastatic breast cancer. Health Psychology, 29(2), 169-180.

Bodenmann, G. (1995). A systemic-transactional conceptualization of stress and coping in couples. Swiss Journal of Psychology, 54(1), 34-49.

Bodenmann, G. (1997). Dyadic coping - a systemic-transactional view of stress and coping among couples: Theory and empirical findings. European Review of Applied Psychology, 47, 137-140.

Bodenmann, G. (2005). Couples coping with stress: Emerging perspectives on dyadic coping. T. A. Revenson, K. Kayser, \& G. Bodenmann (Ed.). Washington, D.C: American Psychological Association.

Bodenmann, G. (2008). Dyadisches Coping Inventar (DCI). [Dyadic Coping Inventory]. Test manual. Bern, Göttingen: Huber \& Hogrefe Testverlag.

Bodenmann, G., \& Cina, A. (2006). Stress and coping among stable-satisfied, stable-distressed and separated/divorced Swiss couples: A 5-year prospective longitudinal study. Journal of Divorce and Remarriage, 44, 71-89.

Bodenmann, G., Meuwly, N., Bradbury, T. N., Gmelch, S., \& Ledermann, T. (2010). Stress, anger, and verbal aggression in intimate relationships: Moderating effects of individual and dyadic coping. Journal of Social and Personal Relationships, 27(3), 408-424.

Bodenmann, G., Meuwly, N., \& Kayser, K. (2011). Two conceptualizations of dyadic coping and their potential for predicting relationship quality and individual well-being. European Psychologist, 16(4), 255-266.

Bradbury, T. N., Fincham, F. D., \& Beach, S. R. H. (2000). Research on the nature and determinants of marital satisfaction: A decade in review. Journal of Marriage and Family, 62(4), 964-980.

Clark, M. S., Lemay, E. P., Graham, S. M., Pataki, S. P., Finkel, E. J. (2010). Ways of giving benefits in marriage: Norm use, relationship satisfaction, and attachment-related variability. 
Psychological Science, 21(7), 944-951.

Compton, W. C. (2005). An introduction to positive psychology. California, CA: Thompson Wadsworth.

Cutrona, C. E., \& Gardner, K. A. (2006). The cambridge handbook of personal relationship. A. L. Vangelisti, \& D. Perlman. (Ed.). New York: Cambridge University Press.

Desai, S., \& Andrist, L. (2010). Gender scripts and age at marriage in India. Demography, 47(3), $667-687$.

Dinas Informasi dan Komunikasi Pemerintah Kota Tangerang. (2010). Pertumbuhan perusahaan industri. Ditemu kembali dari

http://www.tangerangkota.go.id/mobile/detailprofilkota/1/20

Hendrick, S. S. (1988). A generic measure of relationship satisfaction. Journal of Marriage and the Family, 50, 93-98.

Hess, J. (2008). Marital satisfaction and parental stress. Ditemu kembali dari http://digitalcommons.usu.edu/etd/126/

Hoekstra-Weebers, J. E. H. M., Jaspers, J. P. C., Kamps, W. A., Klip, E. C. (1998). Marital dissatisfaction, psychological distress, and the coping of parents of pediatric cancer patients. Journal of Marriage and Family, 60(4), 1012-1021.

Kardatzke, K. N. (2009). Perceived stress, adult attachment, dyadic coping, and marital satisfaction of counseling graduate student. Ditemu kembali dari http://libres.uncg.edu/ir/listing.aspx?id=2322

Kenny, D. A., Kashy, D. A., \& Cook, W. L. (2006). Dyadic data analysis. New York, NY: The Guilford Press.

Kerlinger, F. N., \& Lee, H. B. (2000). Foundation of behavioral research (4th ed.). Belmont, MA: Wadsworth Thomson Learning.

Lederbogen, F., Kirsch, P., Haddad, L., Streit, F., Tost, H., Schuch, P., Wüst, S., Rietschel,

M., Deuschle, M., \& Meyer-Lindenberg, A. (2011). City living and urban upbringing affect neural social stress processing in humans. Nature, 474, 498-501.

Levine, R., Sato, S., Hashimoto, T., \& Verma, J. (1995). Love and marriages in eleven cultures. Journal of Cross-Cultural Psychology, 26(5), 554-571.

Lucas, T., Parkhill, M. R., Wendorf, C. A., Imamoglu, E. O., Weisfeld, C. C., ～Weisfeld, $\quad$ G. E., Shen, J. (2008). Cultural and evolutionary components of marital satisfaction: A multidimensional assessment of measurement invariance. Journal of Cross-Cultural Psychology, 39(1), 109-123. 
Mauno, S. \& Kinnunen, U. (1999). The effect of job stressor on marital satisfaction in Finnish dualearner couples. Journal of Organizational Behavior, 20(6), 879-895.

Olson, D. H., \& DeFrain, J. (2003). Marriages and family intimacy, diversity, and strengths. New York, NY: McGraw-Hill.

Papalia, D. E., Olds, S. W., Feldman, R. D. (2007). Human development (10th ed.). New York, NY: McGraw-Hill.

Papp, L. M., \& Witt, N. L. (2010). Romantic partners individual coping strategies and dyadic coping: Implication for relationship functioning. Journal of Family Psychology, 24(5), 551559.

Randall, A. K. \& Bodenmann, G. (2009). The role of stress on close relationships and marital satisfaction. Clinical Psychology Review, 29, 105-115.

Reis, H. T., \& Sprecher, S. (Eds.). (2009). Encyclopedia of human relationships. California, CA: Sage.

Ruvolo, A. P. (1998). Marital well-being and general happiness of newlywed couples: Relationships across time. Journal of Social and Personal Relationships, 15, 470-489.

Sanders, K. M. (2010). Marital satisfaction across the transition to parenthood. Ditemu kembali dari http://digitalcommons.unl.edu/sociologydiss/2/

Santrock, J. W. (2006). Life-Span Development. New York: McGraw-Hill.

Stone, E. A., \& Shackelford, T. K. (2006). Encyclopedia of social psychology (R. F.

Baumeister \& K. D. Vohs, Ed.). Thousand Oaks, CA: Sage.

Story, L. B. \& Repetti, R. (2006) Daily occupational stressor and marital behavior. Journal of Family Psychology, 20(4), 690-700.

Sugiyono. (2012). Metode penelitian kuantitatif, kualitatif, dan $r \& d$. Bandung: Alfabeta.

Waller, M. R. \& McLanahan, S. S. (2005). "His" and "Her" Marriage Expectations:

Determinants and Consequences. Journal of Marriage and Family 67, 53-67

Yoneda, A. C., \& Davila, J. (2006) . Encyclopedia of stress. G. Fink (Ed.). New York, NY: Elseiver. 